\title{
Serum 25 Hydroxy Vitamin D3 Levels in Type 2 Diabetic Patients
}

\section{Tip 2 Diyabetik Hastalarda Serum 25 Hidroksi Vitamin D3 Seviyeleri}

\author{
Ahmet Cimbek*, Gül Gürsoy, Zuhal Kılıç*, Yaşar Acar*, Berrin Demirbaş**, Murat Bayram*, \\ Nazlı Gülsoy Kırnap*, Fatih Güngör* \\ Kafkas University Faculty of Medicine, Department of Endocrinology, Kars, Turkey \\ ${ }^{*}$ Ankara Hospital, Department of Internal Medicine, Ankara, Turkey \\ **Mesa Hospital, Department of Endocrinology, Ankara, Turkey
}

\begin{abstract}
Aim: Accumulating knowledge suggests that low 25-hydroxyvitamin D3 concentrations may be inversely related to diabetes mellitus and insulin resistance. We planned to investigate the association of 25-hydroxyvitamin D3 levels with some antropometric and metabolic data in type 2 diabetic patients.
\end{abstract}

Methods: In our study including 101 patients with type 2 diabetes mellitus and 60 healthy controls, after making comparisons of 25-hydroxyvitamin D3 levels and other parameters of two groups, we made correlation analysis in our diabetic patients. Later, we grouped our patients according to their 25-hydroxyvitamin D3 levels and made comparisons.

Results: We found significantly lower 25-hydroxyvitamin D3 levels in type 2 diabetic patients than in controls. In correlation analysis, 25-hydroxyvitamin D3 levels were found to be negatively correlated with insulin homeostasis model assessment index. When we grouped our diabetic patients according to 25-hydroxyvitamin D3 levels, no difference was demonstrated in any parameters.

Conclusion: This study suggests that 25-hydroxyvitamin D3 levels are significantly low in type 2 diabetes mellitus. In patients with type 2 diabetes, once vitamin D deficiency exists, metabolic parameters do not worsen according to decreasing vitamin $D$ levels. Since hypovitaminosis $D$ also exists in non-diabetics, we recommend vitamin $D$ supplementation in our population. (The Medical Bulletin of Haseki 2013; 51: 89-94)

Key Words: Type 2 diabetes mellitus, Vitamin D
- Özet

Amaç: Düşük vitamin $D$ konsantrasyonlarının diyabet ve insülin rezistansı ile ters orantılı olduğu konusunda bilgiler çoğalmaktadır. Tip 2 diyabetik hastalarda vitamin D seviyeleri ile bazı antropometrik ve metabolik verileri araştırmayı planladık.

Yöntem: 101 Tip 2 diyabetik hasta ve 60 kontrol ile gerçekleştirdiğimiz çalışmada her iki grubun vitamin D seviyeleri ile diğer parametrelerini kıyasladıktan sonra diyabetik hastalarda korelasyon analizi yaptık, ayrıca 25-hidroksi vitamin D3 seviyelerine göre hastaları sınıflandırıp kıyaslamaları tekrarladık.

Bulgular: Kontrollerle kıyaslandığında diyabetiklerde düşük 25-hidroksi vitamin D3 seviyelerine rastladık. Vitamin D indirekt insülin direnci indeksi ile negatif korele bulundu. Diyabetik hastalar 25-hidroksi vitamin D3 düzeyleri açısından gruplandığında hiçbir parametrede farklılık saptanmadı.

Sonuç: Çalışmamız tip 2 diyabetiklerde 25-hidroksi vitamin D3 seviyesinin belirgin olarak düşük olduğunu ortaya koymuştur. Diyabetik hastalarda vitamin D eksikliği varsa, vitamin seviyeleri azaldıkça metabolik parametreleri daha fazla kötüleşmemektedir. Hipovitaminozis D non-diyabetiklerde de saptandığından toplumumuza vitamin D ilavesinin gerekli olduğunu düşünüyoruz. (Haseki Tıp Bülteni 2013; 51: 89-94)

Anahtar Kelimeler: Tip 2 Diyabetes mellitus, Vitamin D

\section{Introduction}

Vitamin D affects various tissues besides bones, sun exposure and vitamin $D$ intake determines its concentration (1). It has been demonstrated that vitamin
D deficiency is associated with hypertension (2-4), type 1 (T1DM) and type 2 diabetes mellitus (T2DM) (5-11), metabolic syndrome (12-14), cardiovascular disease (1517) and malignancy (18-20).
Address for Correspondence/Yazıșma Adresi: Gül Gürsoy

Kafkas University Faculty of Medicine, Department of Endocrinology, Kars, Turkey E-mail: gulgursoyyener@yahoo.com

Received/Geliş Tarihi: 05 October 2012 Accepted/Kabul Tarihi: 21 January 2013 
Serum concentration of 25-hydroxy vitamin D3(25(OH)D) is the best indicator of vitamin D status (21). Hypovitaminosis $D$ is defined as serum $25(\mathrm{OH}) \mathrm{D}$ concentration $<20 \mathrm{ng} / \mathrm{ml}$ $(22,23)$. The $25(\mathrm{OH}) \mathrm{D}$ concentration was lower in patients with T2DM, than in nondiabetic control subjects $(17,24)$. It has been reported that insulin secretion is dependent upon vitamin D (25-27). It has also been reported that there is a positive correlation of vitamin $\mathrm{D}$ concentration with insulin sensitivity (28-30).

Keeping in mind the complex relationship of vitamin D with glucose metabolism, cardiovascular disease, metabolic syndrome and insulin resistance, we planned to seek the relationship of vitamin $D$ with various parameters in diabetic patients.

\section{Materyal and Methods \\ Patients}

A total of 101 T2DM patients, aged between 30 and 80 years, were recruited from the outpatient clinic at Ankara Education and Research Hospital from January 2011 to February 2011. Sixty healthy age-matched individuals constituted the control group.

Subjects with a history of chronic renal disease and liver disease, skin disorders, malabsorption, inflammatory bowel disease or celiac disease, and those taking medications that may interfere with serum levels of 25(OH)D were excluded.

After detailed physical examination, body weight and height were measured in all subjects. Body mass index (BMI) was calculated as the weight in kilograms divided by the square of the height in meters $\left(\mathrm{kg} / \mathrm{m}^{2}\right)$.

Blood samples were withdrawn after a 12-hour overnight fast, at 08.30 a.m. for measuring fasting plasma glucose (FPG), HbA1c, fasting insulin ( $F I)$, serum total and HDL cholesterol (HDL-C), triglyceride (TG), creatinine, $\mathrm{Ca}$, P, PTH, TSH, albumin and 25(OH)D levels.

An indirect measure of insulin resistance was calculated from the fasting plasma insulin ( $\mu$ unite/ml) x fasting plasma glucose $(\mathrm{mmol} / \mathrm{l}) / 22.5$ formula as homeostasis model assessment (HOMA-IR).

This study was performed according to the principles of the Declaration of Helsinki 2008. The local ethics committee approved this study and all the subjects gave written informed consent.

\section{Laboratory Methods}

Plasma glucose, total cholesterol, TG, creatinine, Ca, P, albumin and HDL-C concentrations were determined by enzymocalorimetric spectrophotometric method using a Roche/Hitachi molecular PP autoanalyzer. Low-density lipoprotein cholesterol (LDL-C) was calculated by the Friedewald Formula (LDL=Total cholesterol - HDL - TG $\div$ 5). Insulin was measured by means of DRG Diagnostics
(DRG Instruments GmbH, Germany) ELISA kits and FI was measured by TOSOH G7 HPLC system. PTH and TSH were determined by chemiluminescence method using the Advia Centaur XP system.

For the measurements of 25(OH)D, Waters LC-MS/ MS device liquid chromatography mass spectrometry was used. We classified 25(OH)D serum levels as follows: 1) $<12 \mathrm{ng} / \mathrm{mL}, 2) 12-20 \mathrm{ng} / \mathrm{mL}$ and 3) $\geq 20 \mathrm{ng} / \mathrm{mL}$.

\section{Statistical Analysis}

Calculations were performed using SPSS version 10.1. Student's t-test was used to compare the groups in a parametric way (for data showing homogeneous dispersion) and the Mann-Whitney $U$ test was used in a non-parametric way (for data showing non-homogeneous dispersion). Correlation between variables was calculated using Pearson's correlation coefficient. Data are presented as mean \pm SD. A p value of less than 0.05 was considered statistically significant.

\section{Results}

This study included 101 patients with T2DM [61 females (61\%) and 40 males (29\%)' yerine 61 females $(61 \%)$ and 40 males (39\%). All the demographic and laboratory findings in the groups were compared and are illustrated in Table 1. In T2DM patients BMI, FBG, HbA1c, $\mathrm{Fl}, \mathrm{HOMA}-\mathrm{IR}, \mathrm{TG}$ levels were significantly higher $(p=<0.01)$ and $25(\mathrm{OH}) \mathrm{D}$ levels were significantly lower than in controls $(p=<0.01)$.

When we made correlation analysis in diabetic patients, we found that $250 \mathrm{HD}$ positively correlated with creatinine $(p=<0.05, r=0.18)$ and negatively correlated with BMI $(p=<0.001, r=-0.23), \mathrm{HbA} 1 \mathrm{c}(p=<0.05, r=-0.21)$, FI $(p=<0.05, r=-0.01)$, HOMA-IR $(p=<0.05, r=-0.20)$, and PTH levels ( $p=<0.05, r=-0.18)$.

Then we classified our diabetic patients according to their $25(\mathrm{OH}) \mathrm{D}$ levels as follows: 1) <12, 2) $12-20$ and 3) $>20 \mathrm{ng} / \mathrm{ml}$ (Table 2 ). We did not find any difference in serum $25(\mathrm{OH}) \mathrm{D}$ levels between the patient subgroups.

\section{Discussion}

Vitamin $D$ is produced in the body after sun exposure and is found in foods. In the body, two hydroxylased forms of vitamin $D$ are present (21). There are three reasons why $25(\mathrm{OH}) \mathrm{D}$ is thought to be a good indicator of vitamin $\mathrm{D}$ state. First; 1,25 $(\mathrm{OH}) 2 \mathrm{D}$ has a shorter half life than 25 $(\mathrm{OH}) \mathrm{D}$, second; its plasma levels are closely related to PTH, Ca and $P$, and lastly, levels of 1,25 (OH) 2D do not decrease until vitamin $D$ deficiency is serious (23).

Vitamin D affects cell growth, immune functions, neuromuscular functions and inflammation (21,23,32-33). There is also mounting interest in the role of vitamin $D$ in the aetiology of T1DM (5-8) and T2DM (9-11) as well as metabolic syndrome (12-14). 
Table 1. Demographic and laboratory findings of the groups

\begin{tabular}{|c|c|c|c|}
\hline & $\begin{array}{l}\text { T2DM } \\
n=101\end{array}$ & $\begin{array}{c}\text { Control } \\
n=60\end{array}$ & $\mathbf{p}$ \\
\hline Age (year) & $55.8 \pm 7.5$ & $51.9 \pm 7.7$ & NS \\
\hline BMI $\left(\mathrm{kg} / \mathrm{m}^{2}\right)$ & $29.8 \pm 4.1$ & $27.2 \pm 2.56$ & $<0.01$ \\
\hline FBG ( $\mathrm{mg} / \mathrm{dl})$ & $172.1 \pm 68.6$ & $92.2 \pm 5.0$ & $<0.01$ \\
\hline HbA1c (\%) & $8.2 \pm 2.1$ & $5.4 \pm 0.2$ & $<0.01$ \\
\hline $\mathrm{FI}(\mu \mathrm{U} / \mathrm{ml})$ & $13.0 \pm 6.4$ & $7.9 \pm 4.0$ & $<0.01$ \\
\hline HOMA-IR & $5.4 \pm 3.6$ & $1.7 \pm 0.9$ & $<0.01$ \\
\hline $\mathrm{TC}(\mathrm{mg} / \mathrm{dl})$ & $198.5 \pm 10.4$ & $188.8 \pm 22.1$ & NS \\
\hline LDL-C (mg/dl) & $127.7 \pm 38.4$ & $124.8 \pm 31.0$ & NS \\
\hline HDL-C (mg/dl) & $44.8 \pm 10.0$ & $29.4 \pm 10.40$ & NS \\
\hline $\mathrm{TG}(\mathrm{mg} / \mathrm{dl})$ & $202.9 \pm 23.5$ & $144.4 \pm 50.0$ & $<0.01$ \\
\hline Creatinine $(\mathrm{mg} / \mathrm{dl})$ & $0.1 \pm 0.04$ & $0.8 \pm 0.1$ & NS \\
\hline $\mathrm{Ca}(\mathrm{mg} / \mathrm{dL})$ & $9.4 \pm 0.3$ & $9.3 \pm 0.5$ & NS \\
\hline $\mathrm{P}(\mathrm{mg} / \mathrm{dL})$ & $3.3 \pm 0.4$ & $3.3 \pm 0.4$ & NS \\
\hline PTH (pg/mL) & $53.6 \pm 25.2$ & $55.2 \pm 18.2$ & NS \\
\hline TSH $(\mu \mathrm{IU} / \mathrm{MI})$ & $1.6 \pm 1.0$ & $1.9 \pm 1.1$ & NS \\
\hline Albumin (g/dL) & $4.3 \pm 0.2$ & $4.3 \pm 0.3$ & NS \\
\hline $25(\mathrm{OH}) \mathrm{D}(\mathrm{ng} / \mathrm{ml})$ & $9.9 \pm 7.6$ & $14.3 \pm 7.7$ & $<0.01$ \\
\hline
\end{tabular}

BMI: Body mass index, FBG: Fasting blood glucose,HbA1c: Hemoglobin A1c, FI: Fasting insulin, HOMA-IR: Homeostasis model assesment index-insulin resistance, TC: Total cholesterol, LDL-C: Low density lipoprotein cholesterol, HDL-C: High density lipoprotein cholesterol, TG: Triglyceride, Ca: Calcium, P: Phosphorous, PTH: Parathyroid hormone, TSH: Thyroid stimulating hormone, 25(OH)D: 25-hydroxy vitamin D. Data are presented as mean \pm SD. NS: nonsignificant.

Table 2. Findings of T2DM patients according to their serum 25(OH)D levels

\begin{tabular}{|c|c|c|c|c|}
\hline $\begin{array}{c}25(\mathrm{OH}) \mathrm{D} \\
(\mathrm{ng} / \mathrm{ml})\end{array}$ & $\begin{array}{c}<12 \\
n=74\end{array}$ & $\begin{array}{l}12-20 \\
n=20\end{array}$ & $\begin{array}{l}>20 \\
n=7\end{array}$ & $p$ \\
\hline Age (year) & $55.3 \pm 7.8$ & $29.7 \pm 6.0$ & $58.7 \pm 7.4$ & NS \\
\hline BMI $\left(\mathrm{kg} / \mathrm{m}^{2}\right)$ & $29.8 \pm 4.1$ & $30.0 \pm 3.06$ & $29.5 \pm 6.4$ & NS \\
\hline FBG $(\mathrm{mg} / \mathrm{dl})$ & $173.4 \pm 71.3$ & $167.2 \pm 55.4$ & $192.8 \pm 55.8$ & NS \\
\hline $\mathrm{HbA1c}(\%)$ & $8.1 \pm 2.2$ & $8.3 \pm 2.0$ & $8.6 \pm 2.1$ & NS \\
\hline $\mathrm{FI}(\mu \mathrm{U} / \mathrm{ml})$ & $13.3 \pm 6.9$ & $12.2 \pm 6.9$ & $12.1 \pm 4.0$ & NS \\
\hline HOMA-IR & $5.2 \pm 4.1$ & $4.8 \pm 2.2$ & $5.4 \pm 1.5$ & NS \\
\hline $\mathrm{TC}(\mathrm{mg} / \mathrm{dl})$ & $88.3 \pm 20.4$ & $186.8 \pm 20.1$ & $201.8 \pm 18.5$ & NS \\
\hline LDL-C (mg/dl) & $129.1 \pm 37.6$ & $122.2 \pm 41.8$ & $129.4 \pm 42.4$ & NS \\
\hline $\mathrm{HDL}-\mathrm{C}(\mathrm{mg} / \mathrm{dl})$ & $44.6 \pm 9.3$ & $43.3 \pm 11.6$ & $50.8 \pm 11.6$ & NS \\
\hline TG (mg/dl) & $206.3 \pm 26.7$ & $206.0 \pm 13.9$ & $168.2 \pm 50.0$ & NS \\
\hline
\end{tabular}

In most $(24,25,34-37)$, but not all (38-40), case-control studies, patients with T2DM are found to have lower serum 25(OH)D concentration compared with controls without diabetes. We also found lower levels of $25(\mathrm{OH})$
D in our diabetic patients, compared to that in controls, in concordance with most of the previous studies. Persons with diabetes are at risk for vitamin D insufficiency and deficiency. Reasons for this include diet, lack of sun 
exposure, obesity, lack of outdoor physical activity, renal impairment and genetic predisposition.

$25(\mathrm{OH}) \mathrm{D}$ levels in the range of 30 to $60 \mathrm{ng} / \mathrm{mL}$ are considered normal (26). Vitamin $\mathrm{D}$ insufficiency has been defined as a $25(\mathrm{OH}) \mathrm{D}$ of $16-30 \mathrm{ng} / \mathrm{mL}$ (41). Vitamin $\mathrm{D}$ deficiency is generally defined as a 25(OH)D below $20 \mathrm{ng} /$ $\mathrm{mL}(22,23)$. The National Health and Nutrition Examination Survey (NHANES) III used a slightly lower value which was $<15 \mathrm{ng} / \mathrm{mL}(42)$. Whatever cutoff value was accepted, our patients' vitamin $D$ levels were significantly low.

The vitamin $D$ levels of our patients were found to be deficient, however, it must be noted that the 25(OH)D levels of our controls were also very low, as it was also determined in another study made in Ankara (43). In the literature, only in a few studies so low 25(OH)D levels were encountered both in patient and control groups $(44,45)$. It was interesting that Al-Daghri et al. $(46)$ found that severe hypovitaminosis $D$ was prevalent in both non-diabetic and diabetics in Saudi adults, but was more common in young and middle aged non-diabetics. Several explanations are possible to describe the reason for very low vitamin D levels both in patient and control subjects. First, the season we have performed our study may affect the vitamin D levels; we made the study during the winter. Second, in our small group of Turkish population, genetic variations must be considered. Third, our clothing style may have affected sun exposure. Fourth, as vitamin D is stored in fatty tissues and less is biologically active in serum, obesity may be linked to the low vitamin D levels in our subjects. The BMI of both diabetics and controls were above the normal range. Fifth, insufficient dietary intake of vitamin D may be another cause of the low levels. Last, lack of outdoor physical activity due to possible obesity or mobility issues and to the season must also be considered.

Vitamin $D$ has various effects on glucose homeostasis. Besides its role in insulin secretion (47), it also has an influence on insulin resistance directly or via $\mathrm{Ca}$ indirectly (48). Ca is essential for insulin mediated-intracellular processes in insulin responsive tissues such as skeletal muscle and adipose tissue. Changes in $\mathrm{Ca}$ in primary insulin target tissues may contribute to peripheral insulin resistance (49) via impaired insulin signal transduction, leading to decreased glucose transporter-4 activity (49). The association between low vitamin $D$ level and insulin sensitivity have been reported in cross-sectional and observational studies (22). The results from the trials on the effect of vitamin $D$ and/or Ca supplementation on insulin resistance have showed improvement on insulin action (50). Supporting the role of vitamin $D$ in both insulin secretion and action, our diabetic patients whose 25(OH)D levels were lower than controls, had higher blood sugar, insulin and $\mathrm{HbA} 1 \mathrm{c}$ levels. 25(OH)D levels in diabetic patients were also found to be negatively correlated with
$\mathrm{HbA} 1 \mathrm{c}$ and FI levels. Diabetic patients were more obese than controls and we showed a negative correlation between BMI and vitamin D. As expected, our diabetics had higher TG levels.

In our diabetic patients, besides significantly low 25(OH)D levels, HOMA-IR levels were significantly high. When we made correlation analysis in diabetic patients, we also found a negative correlation between 25OHD and HOMA-IR. Our results may indicate that vitamin D levels may be related to insulin resistance.

As mentioned before, vitamin $D$ levels in the diabetic group was statistically lower than in the control group, but when we categorized diabetics according to their $25(\mathrm{OH})$ D levels $(<12,12-20$ and $>20 \mathrm{ng} / \mathrm{mL})$, we did not find any difference in the parameters such as blood glucose, insulin, lipids, body mass or insulin resistance index. This result makes us speculate that if vitamin $D$ levels are above normal limits, decline in 25(OH)D levels may not make any change in glucose, lipid metabolism, or obesity or insulin resistance.

In conclusion, we found that vitamin D levels were significantly low in type 2 diabetics compared to nondiabetics. There was an inverse relationship between vitamin D levels and insulin resistance. We also concluded that as vitamin $D$ levels were so low, when vitamin D levels declined in diabetic patients, metabolic parameters did not worsen. Our findings warrant further examination in prospective studies including clinical trials. Our non-diabetic population also had low 25(OH)D levels, thus, we think that in Turkish population, fortified foods in increasing dietary intake of vitamin $\mathrm{D}$ should be encouraged as a component in the treatment plan in combination with supplements of vitamin $D$ and safe sun exposure.

\section{References}

1. Norman AW. Sunlight, season, skin pigmentation, vitamin $D_{\text {, }}$ and 25 hydroxy vitamin D: integral components of the vitamin D endocrine system. Am J Clin Nutr 1998;67:1108-10.

2. Bhandari SK, Pashayan S, Liu IL et al. 25-hydroxyvitamin D levels and hypertension rates. J Clin Hypertens (Greenwich) 2011;13:170-7.

3. Burgaz A, Orsini N, Larsson SC. Blood 25 -hydroxyvitamin D concentration and hypertension: a meta-analysis. J Hypertens 2011;29:636-45.

4. Wuerner G, Burnier M, Waeber B. Hypertension and vitamin D: not again. Rev Med Suisse 2011;7:121-4.

5. EURODIAB Substudy 2 study group. Vitamin D supplement in early childhood and risk for type 1 (insulin dependent) diabetes mellitus. Diabetologia 1999;42:51-4.

6. Soltesz G, Patterson CC, Dahlquist G. EURODIAB Study group worldwide childhood type 1 diabetes incidence- what can we learn from epidemiology? Pediatr Diabetes 2007;8:6-14.

7. Hypönen $E$, Läärä $E$, Reunanen $A$. Intake of vitamin $D$ and risk of type 1 diabetes: a birth cohort study. Lancet 2001;358:1500-3. 
8. Zippitis CS, Akobeng AK. Vitamin D supplementation in early childhood and risk of type 1 diabetes: a sysytemetic review and meta-analysis. Arch Dis Child 2008;93:512-7.

9. Matilla C, Knekt P, Mannisto S et al. Serum 25-hydroxyvitamin D concentration and subsequent risk of type 2 diabetes. Diabetes Care 2007;30:2569-70.

10. Pittas AG, Dawson- Hughes B, Li T et al. Vitamin D and calcium intake in relation to type 2 diabetes in women. Diabetes Care 2006;29:650-6.

11. Thorand B, Zierer A, Huth $C$, et al. Effect of serum 25-hydroxyvitamin $D$ on risk for type 2 diabetes may be partially mediated by subclinical inflammation: results from the MONICA/KORA Augsburg study. Diabetes Care 2011;34:2320-2.

12. Liu S, Song Y, Ford ES, Manson JE, Buring JE, Ridker PM. Dietery Ca, Vitamin D, and the prevelance of metabolic syndrom in middle aged and older US. Women. Diabetes Care 2005;28:2926-32.

13. Ford ES, Ajani UA, Mc Guire LC, Liu S. Concentrations of serum Vitamin D and the metabolic syndrome in US adults. Diabetes Care 2005;28:1228-30.

14. Ford ES, Zhao G, Li C, Pearson WS. Serum concentrations of vitamin $D$ and parathyroid hormone and prevalent metabolic syndrome among adults in the United States. J Diabetes 2009;1:296-303.

15. Zittemann A. Vitamin D and disease prevention with special reference to cardiovascular disease. Prog Biophys Mol Biol 2006;92:39-48.

16. Wang TJ, Pencia MJ, Booth SL, et al. Framingham Heart Study. Vitamin D deficiency and risk of cardiovascular disease. Circulation 2008;117:503-11.

17. Cigolini M, lagulli MP, Miconi V, Galiotto M, Lombardi S, Targher G. Serum 25-hydroxyvitamin D3 concentrations and prevalence of cardiovascular disease among type 2 diabetic patients. Diabetes Care 2006;29:722-4.

18. Autier P, Gandini S. Vitamin D supplemention and total mortality: a meta-analysis of randomized controlled trials. Arch Intern Med 2007;167:1730-7.

19. Kermani IA, Kojidi HT, Gharamaleki JV, et al. Association of serum level of 25 hydroxy-vitamin $D$ with prognostic factors for breast cancer. Asian Pac J Cancer Prev 2011;12:1381-4.

20. Zhang X, Giovannucci E. Calcium, vitamin D and colorectal cancer chemoprevention. Best Pract Res Clin Gastroenterol 2011;25:485-94.

21. Jones G. Pharmacokinetics of vitamin D toxicity. Am J Clin Nutr 2008;88:582-6.

22. Chiu KC, Chu A, Go VI, Saad MF. Hypovitaminosis D is associated with insulin resistance and beta cell dysfunction. Am J Clin Nutr 2004;79;820-5.

23. Holick MF. Vitamin D deficiency. N Eng J Med 2007;357:26681.

24. Scragg R, Holdaway I, Singh V, Metcalf P, Baker J, Dryson E. Serum 25-hydroxyvitamin D3 levels decreased in impaired glucose tolerance and diabetes mellitus. Diabetes Res Clin Pract 1995:27:181-8.

25. Zeitz U, Weber K, Soegiarto DW, Wolf E, Balling R, Erben RG. Impaired insulin secretory capacity in mice lacking a functional vitamin D receptor. FASEB 2003;17:509-11.

26. Clark SA, Stumpf WE, Sar M. Effect of 1,25 dihydroxyvitamin D3 on insulin secretion. Diabetes 1981;30:382-6.
27. Johnson JA, Grande JP, Roche PC, Kumar R. Immunohistochemical localization of the 1,25(OH)2D3 receptor and calbindin D28k in human and rat pancreas. Am J Physiol 1994;267:356-60.

28. Maestro B, Campion J, Davila N, Calle C. Stimulation by 1, 25 dihydroxy vitamin D3 of insulin receptor expression and insulin responsiveness for glucose transport in U-937 human promonocytic cells. Endocr J 2000;47:383-91.

29. Williams PF, Caterson ID, Cooney GJ, Zilkens RR, Turtle JR. High affinity insulin binding and insulin receptor effector coupling: modulation by Ca 2+. Cell Calcium 1990;11:547-56.

30. Zemel MB. Nutritional and endocrine modulation of intracellular calcium: implications in obesity, insulin resistance and hypertension. Mol Cell Biochem 1998;188:129-36.

31. Buell JS, Tucker KL. The value of physiologic vitamin $D$ as a biomarker of demantia. Drugs Today(Barc) 2011;47:223-31.

32. Akbar NA, Zacharek MA. Vitamin D: immunomodulation of asthma, allergic rhinitis, and chronic rhinosinusitis. Curr Opin Otolargyngol Head Neck Surg 2011;19:224-8.

33. Cooper JD, Smyth DJ, Walker NM, et al. Inherited variation in vitamin $\mathrm{D}$ genes is associated with predisposition to autoimmune disease type 1 diabetes. Diabetes 2011;60:162431.

34. Hyppönen E, Power C. Vitamin D status and glucose homeostasis in the 1958 British birth cohort: the role of obesity. Diabetes Care 2006;29:2244-6.

35. Christansen C, Christansen MS, McNair P, Nielsen B, Madabad S. Vitamin $D$ metabolites in diabetic patients; decreased serum concentrations of 24,25-dihydroxyvitamin D. Scand J Clin Lab Invest 1982;42:487-91.

36. Tahrani AA, Ball A, Shepherd L, Rahim A, Jones AF, Bates A. The prevelance of vitamin $D$ abnormalities in South Asians with type 2 diabetes mellitus in the UK. Int J Clin Pract 2010;64:351-5.

37. Aksoy H, Akçay F, Kurtul N, Baykal O, Avcı B. Serum 1, 25-dihydroxyvitamin $D$, 25-hydroxyvitamin $D$ and parathormone levels in diabetic retinopathy. Clin Biochem 2000;33:47-51.

38. Nyomba BL, Bouillon R, Bidingja M, Kandingu K, De Moor P. Vitamin $D$ metabolites and their binding protein in adult diabetic patients. Diabetes 1986;35:911-5.

39. Ishida H, Seino Y, Matsukura S et al. Diabetic osteopenia and circulating levels of vitamin D metabolites in type 2 (noninsulin dependent) diabetes. J Nutr Sci Vitaminol (Tokyo) 1985;31:27-32

40. Heath 3rd H, Lambert PW, Service FJ, Arnaud SB. Calcium homeostasis in diabets mellitus. JCEM 1979;49:462-6.

41. Binkley N, Novotny R, Kruger D et al. Low vitamin D status despite abundant sun exposure. JCEM 2007;92:2130-5.

42. Nesby-O'Donnel S, Scanlon KS, Cogswell ME et al. Hypovitaminosis D prevalence and determinants among African American and white women of reproductive age: Third National Health and Nutrition Examination Survey, 1988-1995. Am J Clin Nutr 2002;76:187-92.

43. Arasıl T, Uysal AR, ídil A et al. Ankara'da yaşıyan kadınlarda D vitamini durumu. Tur JEM 2010;14:39-43.

44. Stěpán J, Wilczek $H$, Justová $V$, et al. Plasma 25-hydroxycholecalciferol in oral sulfonylurea treated diabetes mellitus. Horm Metab Res 1982;14:98-100. 
45. Pietschmann P, Schernthaner G, Woloszczuk W. Serum osteocalcin levels in diabetes mellitus: analysis of the type of diabetes and microvascular complications. Diabetologia 1988;31:892-5.

46. Al-Daghri NM, Al-Attas OS, Al-Okail MS et al. Severe hypovitaminosis $\mathrm{D}$ is widespread and more common in non-diabetics than diabetics in Saudi adults. Saudi Med J 2010;31:775-80.

47. Borissova AM, Tankova T, Kirilov G, Dakovska L, Kovacheva R. The effect of vitamin D3 on insulin secretion and peripheral insulin sensitivity in type 2 diabetic patients. Int J Clin Pract 2003;57:258-61.
48. Maestro B, Campion J, Davila N, Calle C. Stimulation by 1, 25 dihydroxy vitamin D3 of insulin receptor expression and insuli,n responsiveness for glucose transport in U-937 human promonocytic cells. Endocr J 2000;47:383-91.

49. Zemel MB. Nutritional and endocrine modulation of intracellular calcium: implications in obesity, insulin resistance and hypertension. Mol Cell Biochem 1998;188:129-36.

50. Nazarian S, St Peter JV, Boston RC, Jones SA, Mariash CN. Vitamin D3 supplementation improves insulin sensitisity in subjects with impaired fasting glucose. Transl Res 2011;158:276-81. 